\title{
A stresszkezelés alkalmazási lehetőségei az elhízás kezelésében
}

\author{
Czeglédi Edit dr.
}

\author{
Semmelweis Egyetem, Általános Orvostudományi Kar, \\ Magatartástudományi Intézet, Budapest
}

\begin{abstract}
Az elhízás etiológiájában kitüntetett jelentőséggel bíró életmód (túltáplálkozás és fizikai inaktivitás) hátterében gyakorta pszichológiai tényezők húzódnak meg. A krónikus stressz hozzájárulhat a diéta betartását akadályozó magatartásokhoz (például rendszertelen étkezés, emocionális evés) és a fizikai inaktivitáshoz egyaránt. A randomizált kontrollcsoportos vizsgálatok eredményei szerint a relaxáció alkalmazása csökkenti az érzelmi evést, javítja a táplálékbevitel kognitív korlátozását és ezáltal elősegíti a súlycsökkenést. A stresszkezelés azonban túlmutat a relaxáción: adaptív problémafókuszú és emóciófókuszú megküzdési módokat, valamint kapcsolatépítő készségeket is magában foglal. A feszültséglevezető készségek segíthetnek az érzelmi evés más viselkedésekkel történő kiváltásában. A kognitív újrastrukturálás, a nemet mondás és a problémamegoldás technikája pedig hozzájárulhat azon konfliktusok és nehézségek megelőzéséhez vagy hatékony kezeléséhez, amelyekből az evésrohamok révén levezetést nyerő feszültségek származnak. A stresszkezelő készségek fejlesztése növelheti a páciensek együttmúködését a súlycsökkentő kezelés során. A tanulmányban ismertetett módszerek a családorvosi és szakorvosi praxisban is könnyen megvalósíthatók, illetve támpontokat adhatnak az elhízott páciensek kezelésének optimalizálásához. Orv. Hetil., 2016, 157(7), 260267.
\end{abstract}

Kulcsszavak: stressz, elhízás, stresszkezelés, az elhízás kezelése, testsúlykontroll

\section{Options of stress management in obesity treatment}

\begin{abstract}
Overeating and physical inactivity are of great importance in the etiology of obesity. Psychological factors are often found in the background of life style. Chronic stress can contribute to physical inactivity and behaviors that hinder the keeping of a diet (e.g., irregular eating pattern, emotional eating). Results of randomized controlled trials show that relaxation can reduce emotional eating, improve cognitive restraint, and thereby reduce weight. However, stress management is more than relaxation. It consists of adaptive emotion-focused and problem-focused coping strategies and skills to improve relationships. Deflection skills may help in replacing emotional eating with other behaviors. Cognitive restructuring, saying no, and problem solving help to prevent or manage conflicts and difficulties otherwise would result in overeating due to distress. Developing stress management skills may result in greater compliance with the treatment. The techniques presented in the study can be easily applied by general practitioners or specialists, and provide tools for optimizing obesity treatment.
\end{abstract}

Keywords: stress, obesity, stress management, obesity treatment, weight management

Czeglédi, E. [Options of stress management in obesity treatment]. Orv. Hetil., 2016, 157(7), 260-267.

(Beérkezett: 2015. november 20.; elfogadva: 2015. december 17.)

Az elhízás az egyénre és a társadalomra egyaránt súlyos terheket rovó, az Egészségügyi Világszervezet által a tíz legsúlyosabb betegség közé sorolt, a korai mortalitás kockázatát jelentősen növelő állapot [1]. A legutóbbi, reprezentatív Európai Lakossági Egészségfelmérés eredményei szerint Magyarország felnőtt lakosságának 54\%-a túlsúlyos vagy elhízott. A túlsúly előfordulási gyakorisága a férfiak körében $39 \%$, a nők körében $28 \%$. Az elhízás a férfiak 21\%-át, míg a nők 20\%-át érinti [2]. Az Iskoláskorú gyermekek egészségmagatartása elnevezésű, nemzetközi, négyévente ismétlődő reprezentatív kutatás 2010-ben felvett hazai adatai szerint a serdülőkorú 
(11,5-17,5 éves) fiúk körében a túlsúly előfordulási gyakorisága 15,0-18,8\%, az elhízásé 2,5-4,1\%. A lányoknál a túlsúly prevalenciája $7,2-12,1 \%$, az elhízás előfordulási gyakorisága pedig $1,3-1,7 \%$ volt [3].

Az elhízás multifaktoriális etiológiájában az életmód - nevezetesen a túltáplálkozás és a fizikai inaktivitás - kitüntetett szereppel bír. Az életmód alakulására viszont egyes pszichológiai tényezók rendkívül nagy hatást gyakorolhatnak, mint amilyen többek között a mentális egészség (például depresszió) [4] vagy a stressz. A stressz az életünk szerves része, Selye János szerint „sava-borsa” [5], azonban a tartós, kezeletlen pszichológiai stressz káros hatásai jól ismertek. Ráadásul a súlyfelesleggel élők a mindennapi életben megjelenő pszichés stresszforrásokon túl további megterhelésnek is ki vannak téve. A nyugati társadalomban ugyanis rendkívül kedvezőtlen az elhízás megítélése. Az elhízás stigmatizációja, az elhízottak negatív diszkriminációja széles körben elterjedt és áthatja az élet számos területét (például oktatás, foglalkoztatás, egészségügy) [6]. Az elhízás esetében a stigmát a testsúllyal kapcsolatos negatív attitúdök és hiedelmek képezik, amelyek sztereotípiában, előítéletben és elutasításban manifesztálódnak. A stigma nyílt és burkolt formában egyaránt megnyilvánulhat és többféle módon is jelentkezhet, úgymint verbális vagy fizikai bántalmazás; illetve kapcsolati viktimizáció (például társas kirekesztés, elkerülés és pletykálás) [7]. E témakör az Egyesült Államokban rendkívül intenzíven kutatott [6-8] és újabban hazánkban is vizsgálják [9-11]. A negatív előítélet és diszkrimináció krónikus stresszorként konceptualizálható, amely káros hatást gyakorolhat az emocionális jóllétre. Mivel a társadalom elóítélettel viseltetik irántuk, az elhízott emberek várhatóan több pszichológiai distresszt élnek át, mint az átlagos súlyúak [12].

A helyzetet súlyosbítja, hogy az elhízás maga is stresszforrás lehet. Saját klinikai tapasztalataim szerint a súlyfelesleggel küzdők számára például kellemetlen élmény vékony emberek között lenni, strandra menni; nehezükre esik intim kapcsolatokat kezdeményezni; de a mobilitás (például lépcsőn járás) csökkenése, a testápolás és a személyes higiénia tartásának nehezítettsége, illetve az öltözködési lehetőségek korlátozott volta mind hozzájárulhatnak a pszichológiai distressz érzéséhez. Nem beszélve arról, hogy a családorvosi rendelőkben a legritkább esetben állnak rendelkezésre megfelelő méretú vérnyomásmérő mandzsetták vagy $150 \mathrm{~kg}$ feletti súlytartomány mérésére is alkalmas személymérlegek, ami ugyancsak kínos, esetenként megalázó helyzetbe hozhatja a pácienseket.

A stressz oly módon játszik szerepet a súlyfelesleg kialakulásában, hogy interakcióba léphet az energiabevitellel és az energialeadással [13]. Az energialeadásra gyakorolt hatásra példa, hogy a prospektív kutatások eredményei szerint a pszichológiai stressz előre jelzi az alacsonyabb mértékű fizikai aktivitást, illetve testgyakorlást, valamint a nagyobb mértékü ülő életmódot [14]. $\mathrm{Az}$ energiabevitelre gyakorolt hatásra példa, hogy a stressz megnöveli az étvágyat a hedonikus, ízletes és nagy energiasürúségú ételek iránt [15].

Az elhízásra hajlamosító (úgynevezett obesogen) evési magatartások hátterében az áll, hogy az evés messze túlmutat a létfenntartás funkcióján, mert pszichológiai funkciókat is betölthet az egyén számára. Szolgálhat például a társas kapcsolatok szabályozójaként, örömforrásként, önjutalmazásként, az öngondoskodás módjaként vagy érzelemszabályozási stratégiaként. Az érzelmi evés (vagy emocionális evés) a negatív érzelmekkel és élményekkel (mint például stressz, magányosság, unalom, szorongás) való megküzdési stratégia [16]. Az emocionális éhség és a fizikai éhség számos megkülönböztető jellemzővel bír. Az emocionális éhséget érzelmi trigger váltja ki, hirtelen tör az emberre, azonnali kielégülést kíván, túlevéshez vezethet és bûntudatot kelthet. A fizikai éhség ezzel szemben a fiziológiai szükségletek eredményeképpen, fokozatosan jelenik meg. Az evés késleltethető, a telítődési jelekre nagy valószínúséggel abbamarad és kevéssé kelt büntudatot [17]. Az érzelmi evésre való hajlam mérésére elérhető magyar nyelven a 21 tételes Háromfaktoros Evési Kérdőív [18, 19], amelynek Érzelmi evés skálája a jelen tanulmány Függelékében újraközlésre kerül.

Az érzelmi evésre való hajlam magasabb testtömegindexszel jár együtt [20], illetve hosszú távon súlygyarapodást eredményez [21, 22]. Mindennek hátterében az állhat, hogy az érzelmi evésre való tendencia kapcsolatot mutat a hizlaló ételek megnövekedett fogyasztási gyakoriságával [23]. Ebben jelentős szerepet tölthet be az a neurokémiai mechanizmus, hogy a szénhidrátfogyasztás az inzulinszekréció és a plazmatriptofán arányának növelése útján fokozza a szerotonin kibocsátását. Az agy szerotoninszintjének emelkedése a fájdalom csökkenésével és a hangulat javulásával jár együtt, így az emberek megtanulhatják, hogy ha nagy mennyiségű szénhidrátot (például édességeket) fogyasztanak, akkor jobban fogják érezni magukat. Bizonyos ételek szinte drogként történő fogyasztása gyakori oka a súlynövekedésnek [24].

A professzionális súlycsökkentő kezelések, a mütéti eljárás kivételével, csak szerény mértékű (5-10\%-os) és rövid távú fogyást eredményeznek [25]. Mindebben jelentős szerepet játszik a pszichológiai tényezók figyelmen kívül hagyása, mint amilyen például a változásra való készenlét [26], a fogyás révén elérni remélt célok [27], a gondolkodási stílus [28] vagy az érzelmi evésre való hajlam [29]. Fontos belátnunk azt, hogy ha a páciens érzelemszabályozásra, unaloműzésre, önjutalmazásra vagy egyéb, ehhez hasonló célokra használja az evést, akkor jelentős nehézséget fog okozni a számára a szakember által előírt, alacsony kalóriatartalmú diéta betartása. És azt is szükséges felismernünk, hogy ebben az esetben nem a motiváció hiányáról, a páciens értetlenségéről vagy (horribile dictu) „tohonyaságáról” van szó, hanem egy maladaptív megküzdési stratégiáról, amelynek figyelmen kívül hagyása előrevetíti a kezelés sikertelenségét. Éppen ezért az érzelmi evésre való hajlam felmérése és a 
stresszkezelő készségek integrálása a tradicionális testsúlycsökkentő kezelésekbe növelheti a páciensek együttmúködését és elősegítheti a hosszú távú testsúlykontroll sikerességét.

\section{A stresszkezelés additív hatása a testsúlycsökkentő kezelésekben}

Manzoni és mtsai [30, 31] Olaszországban folytatott, prospektív, négy hónapos időintervallumot felölelő randomizált, kontrollcsoportos vizsgálatában egy kórházi súlycsökkentő kezelés érzelmi evésre hajlamos női páciensei vettek részt ( $\mathrm{n}=36, \mathrm{BMI} \geq 30$, az életkor terjedelme: 18-60 év). A standard, többkomponensű kezelés öt hétig tartott, alacsony kalóriatartalmú diétát, testgyakorlást, csoportos táplálkozásismeretet és heti egy alkalommal 45 perces egyéni kognitív viselkedésterápiás konzultációt foglalt magában. A résztvevők egyharmada ezenfelül nem kapott további kezelést (kontrollcsoport), kétharmaduk (intervenciós csoport) viszont három héten keresztül, heti négy alkalommal, hangfelvétellel vezérelt relaxációs tréningben is részesült (progresszív izomrelaxáció, alkalmazott relaxáció), két kísérleti feltételben (virtuális valóság vs. imagináció). Az eredmények szerint a negyedik hónap végén az érzelmi evésre való hajlam mindkét intervenciós csoportban szignifikánsan csökkent, míg a kontrollcsoportban nem változott. A szorongás csak a virtuális valóság csoportban csökkent szignifikánsan. A depresszió mindkét intervenciós csoportban szignifikánsan csökkent, a kontrollcsoportban nem változott. Az evés kontrollálásában észlelt énhatékonyság mindkét intervenciós csoportban szignifikánsan nőtt, míg a kontrollcsoportban nem változott. Végül a testtömeg mindhárom csoportban szignifikánsan csökkent.

Christaki és mtsai [32] Görögországban folytattak hasonló vizsgálatot. A prospektív, randomizált, kontrollcsoportos vizsgálat nyolchetes időintervallumot ölelt fel. A résztvevők az athéni elhízásklinika női páciensei voltak ( $\mathrm{n}=34, \mathrm{BMI}>28$, átlagéletkor: 47,4 év, SD = 11,64 év). $\mathrm{Az}$ ambuláns kezelés során a résztvevők három alkalommal (a program elején, közepén és végén) húszperces, egyéni, diétás konzultációban részesültek, amely során alacsony kalóriatartalmú, kiegyensúlyozott (mediterrán) étrendet írtak elő nekik, 600 Kcal energiadeficit célkitûzéssel. A kontrollcsoport semmilyen további kezelést nem kapott. Az intervenciós csoport stresszkezelő programban is részt vett, három, alkalmanként negyven percig tartó egyéni konzultáció keretében, amely konzultációkat a program elejére, közepére és végére időzítettek. A résztvevők $C D$ segítségével elsajátították a progresszív izomrelaxációt és a diafragmatikus légzést, amit az előírás szerint napi két alkalommal kellett gyakorolniuk nyolc héten keresztül. Az eredmények szerint a testtömeg az intervenciós csoportban szignifikánsan nagyobb mértékben csökkent, az evés kognitív korlátozása pedig szignifikánsan nagyobb mértékben növekedett, mint a kontrollcsoportban. Az érzelmi evésre való hajlam és az észlelt stressz tekintetében nem mutatkozott szignifikáns különbség a változás mértékében. Megjegyzendő, hogy az elemzéseket az életkor, az érzelmi evés és a családi állapot kontrollja mellett végezték el, illetve, hogy az intervenciós csoport érzelmi evésre való hajlama a kiindulásnál szignifikánsan és statisztikai értelemben nagymértékben magasabb volt, mint a kontrollcsoporté.

A fenti eredmények az alacsony mintaelemszámból fakadó alacsony statisztikai erő és a rövid vizsgálati időintervallum ellenére is ígéretesnek tûnnek, és rámutatnak arra, hogy a stresszkezelés révén jelentősen csökkenthető a maladaptív, a súlyfelesleg kialakulásában és fennmaradásában szerepet játszó evési magatartások előfordulási gyakorisága. Az érzelmi indíttatású falásrohamok kiküszöbölésével pedig akár szigorú étrendi megszorítások nélkül is el lehet érni a hosszú távú, stabil testsúlycsökkenést.

\section{A stresszkezelés relaxáción túlmutató stratégiáinak alkalmazási lehetőségei a testsúlykontrollban}

Noha a relaxáció bizonyítottan hatékony feszültségcsökkentő módszer, a stresszkezelés messze túlmutat a relaxáción. Számos olyan készséget is magába foglal, amelyek segítenek hatékonyan kezelni a problémákat, illetve interperszonális konfliktusokat, elősegítik a túlterheltség és a konfliktusok megelőzését, vagy más módon járulnak hozzá az intraperszonális feszültség és distresszérzés csökkentéséhez. E készségek közül jó pár szerves részét képezi az elhízás kognitív és viselkedésterápiás megközelítéseinek [25, 33].

Erre példa a problémamegoldás stratégiája, amelynek lényege a probléma meghatározása, a cél kitűzése, a lehetséges megoldások felsorakoztatása, az optimálisnak túnő megoldás(ok) kiválasztása és végrehajtása, majd az eredmény értékelése, és ennek fényében a választott megoldás megtartása vagy módosítása [34]. Mivel a testsúlykontroll élethosszig tartó feladat és tartós erőfeszítéseket igényel az étrendi korlátozás, illetve a fizikai aktivitás tekintetében, ez a stratégia különösen hasznos lehet a (túl)fogyasztást és a fizikai inaktivitást promotáló, obesogen környezetben. A fizikai aktivitás elégtelensége többek között a fizikai teherbírás csökkenésének; a sportolással kapcsolatos szégyenérzetnek, illetve negatív diszkriminációnak; a modern, gépesített környezetünknek, illetve a munkahelyi és/vagy magánéleti túlterheltségnek az eredménye. Ez azért különösen sajnálatos, mert a fizikai aktivitás - különösen az állóképesség típusú, elegendő intenzitással, időtartamban és gyakorisággal végzett testgyakorlás - kedvező hatást gyakorol a súlyvesztésre, a teljes zsírtartalomra és a testzsír eloszlására. A rendszeres fizikai aktivitás és az ebből származó fittség még akkor is számtalan egészségügyi előnnyel járhat, ha az elhízott személyek nem fogynak [35]. A fizikai 
aktivitás emellett a mentális egészség alakulásában is jelentős szerepet játszik [36], ami például a depresszió és az emocionális evésre való hajlam ismert kapcsolata [23] fényében különösen fontos. Az is gyakori jelenség, hogy a súlycsökkentő kezelés során a páciens a nap folyamán betartja az alacsony kalóriatartalmú diétát, azonban védtelen az este, vacsora után rátörő éhséggel szemben, amikor az evés az egész napos helytállás jutalmaként funkcionál. Ha mindez nem is eredményez falásrohamot és csak pár száz kalóriás energiabevitellel jár is, a diéta sikertelenségéhez vezethet. Éppen ezért a problémamegoldás stratégiája különösen hasznos lehet ezekben az esetekben.

A figyelemelterelés, illetve a viselkedéses belyettesités ugyancsak jól ismert stratégiák a kognitív viselkedésterápiából [34]. Az utóbbi lényege a maladaptív viselkedés felváltása egy adaptív viselkedéssel. Tapasztalataim szerint az érzelemszabályozási célból evők tisztában vannak azzal, hogy az evés célja a feszültségük csökkentése, ezért az örömteli tevékenységek felsorakoztatásával a cselekvések egész tárháza áll a rendelkezésükre a figyelmük elterelésére az emocionális éhségükről, illetve az evés helyettesítésére az ilyen helyzetek esetében. Az 1. táblázatban felsorolok néhány, a saját klinikai munkámból származó példát. Mivel az érzelmi evésre hajlamos elhízottak jelentős része az öngondozásnak csak egyetlen módját, nevezetesen az evést ismeri, és van olyan terápiás megközelítés, amelynek egyik fókuszpontja az öngondozás képességének javítása abból a célból, hogy csökkenjen az elhízott páciensek ételtől való függősége, és ezáltal lehe\begin{tabular}{l|l} 
1. táblázat & $\begin{array}{l}\text { Példák a viselkedéses helyettesítésre az érzelmi evés kiváltása cél- } \\
\text { jából }\end{array}$
\end{tabular}

Zenét hallgatok.

Énekelek.

Olvasok.

Beszélgetek.

Táncolok.

Mással foglalkozom konstruktív

módon.

Belefogok egy addig halogatott

feladatba

Megterhelő feladattal kezdek

foglalkozni.

Megtervezem a napi teendőimet.

Megtervezem a következő

utazásomat.

Álmodozom.

Lefekszem aludni.

Relaxálok.

Meditálok.

Sportolok.

Küzdősportot űzök.

Bokszzsákot püfölök

Kilépek a helyzetből.

Keresztrejtvényt fejtek.

Házimunkát végzek.

Szótárt tartok magamnál

és a várakozások ideje alatt

szavakat tanulok. tővé váljon számukra a viselkedésük megváltoztatása [29], különösen fontosnak és hasznosnak tartom az önjutalmazás és öngondoskodás evésen túlmutató, adaptív módjainak megjelenését a példák között (például szépségápolás, masszázs). Érdemes azt is kiemelni, hogy a relaxációhoz hasonlóan az örömteli tevékenységek folytatása is elősegíti a feszültség és distressz érzésének csökkenését.

A feszültség, illetve distressz csökkentésére szolgál a kognitív terápia egyik alapstratégiája, a kognití újrastrukturálás (vagy átkeretezés) is. E stratégia lényege az irreális gondolatok felismerése, valóságtartalmának megkérdőjelezése és helyettesítése a tényekből jobban következő, reálisabb gondolatokkal [34]. Vegyük a gyakori, „kövér vagyok, ezért nem kellek senkinek” gondolat példáját, amely hiedelem jellemzően szomorúsággal, kétségbeeséssel vagy értéktelenség érzésével tölti el a személyt. Ráadásul a negatív érzések következtében a személy magatartása úgy fog alakulni, mintha igaz lenne ez a gondolat. Azaz a testét takargatni szándékozó - de valójában előnytelen - fekete lebernyegekbe fog öltözni, visszahúzódó lesz, elkerüli az ismerkedés lehetőségét, ha pedig mégiscsak közeledni próbálna hozzá valaki, akkor félreértelmezi és ezért elutasítja a közeledést. Mindennek következtében fent is tartja azt az állapotot, amelytől fél (azaz a gondolata önbeteljesítő jóslatként múködik), ami a - valójában torz, irreális - gondolat és a hozzá kapcsolódó distresszérzés állandósulásához vezet, ördögi kört eredményezve. A címkézésre való hajlam (például „akaratgyenge vagyok”) mint kognitív torzítás pedig azért különösen veszélyes, mert azon túl, hogy rossz érzést, illetve büntudatot kelt, fel is menti az egyént az erőfeszítések alól. Az elhízottakra különösen jellemző a dichotóm (fekete-fehérben való) gondolkodás (például „Ha túlléptem a kalórialimitemet, nincs már értelme erôfeszitéseket tennem, ezért aztán azt eszem, amit akarok!"), amely kognitív torzításra való hajlam bizonyítottan szerepet játszik a visszahízásban [37]. Éppen ezért a kognitív újrastrukturálás alkalmazása igen jótékony lehet a testsúlykontrollra törekvő súlyfelesleggel bírók esetében. Az irreális gondolatok átkeretezése jelentős feszültségcsökkenést eredményez. Az egyik páciensem például ráébredt arra, hogy „a harag oka a belyzet értelmezése”, és amennyiben máshogy értelmezi az adott személy viselkedését egy adott helyzetben, akkor nem (vagy az eredetinél jóval kisebb intenzitású) haragot fog érezni, hanem például sajnálatot. Az átkeretezés azért is hasznos, mert a reális gondolatok támpontokat adnak a változáshoz, illetve a változtatáshoz. Például a már említett „Akaratgyenge vagyok!” gondolat helyettesítése az „Amikor fáradt és feszült vagyok, nehezemre esik megállni, hogy finomságokkal vigasztaljam magam” gondolattal rámutat arra, hogy mely állapotokban, illetve helyzetekben veszélyeztetett a páciens maladaptív evési magatartásra. A konkrét probléma megfogalmazása pedig a konkrét cél kijelölését és az annak elérésére szolgáló konkrét viselkedés(ek) meghatározását teszi lehetővé, például a problémamegoldás stratégiájá- 
nak alkalmazásával. Így az adott helyzetben vagy érzelmi állapotban megjelenő érzelmi evés problémája kezelhetővé, megoldhatóvá válik, elősegítve, hogy a páciens betartsa a napi kalóriakorlátozást. Másik oldalról közelítve, ha egy személy sok konfliktust és ennek következtében fokozott distresszt él át, mert például felelőtlennek tartja a partnerét, aki vezetés közben állítja be az autó navigációs rendszerén az úti célt, akkor ennek a címkéző gondolatnak az átfogalmazása (például: „Nem felelötlen, csak túlontúl bizik a vezetési képességeiben, amire viszont meg is van az alapja, hiszen élete során még nem okozott vagy szenvedett balesetet”) egyfelől csökkenti a belső feszültséget, másfelől megnyitja az utat a partner feszültséget okozó konkrét viselkedésének megváltoztatása felé, például az asszertív kommunikáció alkalmazásával. A 2. táblázatban bemutatok néhány példát a saját klinikai munkámból az irreális gondolatokra, és ezek lehetséges átkeretezésére.

Elhízásra hajlamosító környezetünkben a hatékony testsúlykontroll állandóan megköveteli a csábításnak való ellenállást. Kultúránkban a szeretet és az etetés, illetve evés szorosan összekapcsolódik, amely kapcsolat a csecsemókorban kezdődik és sokak számára az egész életük során fent is marad [29]. Mindez a reklámokban is tetten érhető, amikor például „a kenyérre kenhető szeretet” jelenik meg egyes élelmiszerek szlogenjeként. Az ételt, süteményt kínáló édesanya, nagymama pedig nemcsak a hozzávalókat fózi vagy süti bele az ételbe, hanem a szívét is. Ez is hozzájárul a vehemens kínáláshoz, jellemzően az „Ez a szelet sütemény/tányér étel nem fog megártani!”

\section{2. táblázat | Példák a kognitív újrastrukturálásra}

\begin{tabular}{ll}
\hline Eredeti gondolat & Átkeretezett gondolat \\
\hline Elszúrtam a diétámat, ezért most & Ezzel a süteménnyel 400 \\
már bármit megehetek, úgyis & kalóriával túlléptem a mai \\
mindegy. & kalórialimitemet. De ha ma \\
& már csak gyümölcsöt fogyasztok \\
& és az elkövetkezendö öt napban \\
& minden nap 100 kalóriával \\
kevesebbet eszem, sikeresen & kompenzálni tudom ezt a \\
& botlásomat.
\end{tabular}

\begin{tabular}{ll}
\hline Akaratgyenge vagyok. & $\begin{array}{l}\text { Amikor fáradt és feszült vagyok, } \\
\text { nehezemre esik megállni, hogy } \\
\text { finomságokkal jutalmazzam/ } \\
\text { vigasztaljam magam. }\end{array}$ \\
\hline Dagadt disznó vagyok. & Súlyfelesleggel élek. \\
\hline A kövérségem miatt nem kellek & $\begin{array}{l}\text { Noha a mai szépségideál a } \\
\text { karcsú, azért mégis akadnak } \\
\text { olyan férfiak, akik vonzónak } \\
\text { tartják a telt testalkatú nőket. }\end{array}$ \\
\hline $\begin{array}{l}\text { Kövér vagyok, ezért tökéletes } \\
\text { feleségnek kell lennem. }\end{array}$ & $\begin{array}{l}\text { Bár nem vagyok karcsú, ettől } \\
\text { még lehetek vonzó és szerethető } \\
\text { feleség. }\end{array}$ \\
\hline Egy 100 kg feletti nő sosem & $\begin{array}{l}\text { Egy súlyfelesleggel bíró nő } \\
\text { nehezebben tud megfelelni a női } \\
\text { lehet igazi nő. }\end{array}$ \\
\hline
\end{tabular}

mondat kíséretében. Éppen ezért nemet mondani az ételkínálásra bántó vagy akár sértő is lehet a másik fél számára, amit sokan nem mernek megkockáztatni, inkább megkóstolják vagy akár meg is eszik a felkínált ennivalót. Csakhogy a kínáló fél kevéssé tájékozott arról, hogy a diétázóknak általában nincsen alternatív terve a diéta megszegésére. Ha ugyanis elfogadják és megeszik a felkínált ételt, ezt többnyire úgy értelmezik, hogy elrontották az aznapi diétájukat, ami a búntudat és szégyenérzet kialakulását eredményezi, tovább gyengítve az önkontrollt, ami további evéshez vezet [38]. A katasztrofizáló gondolatok átkeretezése sokat segíthet eme önrontó kör megakasztásában [39], azonban a fentiek fényében a nemet mondás különösen hasznos lehet a súlyfelesleggel küzdők számára. E készség hatékony alkalmazásával ráadásul a súlyfelesleggel élők nemcsak a diétájuk betartását veszélyeztető kísértésekkel tudnak sikeresen megküzdeni, hanem a túlterheltséggel is. A munkahelyi vagy magánéleti túlvállalás ugyanis a fizikai aktivitás csökkenése mellett olyan belső feszültséget is eredményezhet, amelynek a csillapítására felléphet az érzelmi evés. A túlvállalás további folyománya lehet az éjszakázás. Az éjszakai munka viszont energiát igényel és az energiapótlás legkézenfekvőbb eszköze az evés. Így ismét kirajzolódik egy út, ami a pozitív energiamérleghez vezet, még a megfelelő motiváció és a kezelési együttmúködésre való hajlandóság esetében is.

\section{Megbeszélés}

Az elhízás a XXI. század pandémiájává vált, ami a kezelés mellett a prevenció fontosságát is előrevetíti, különösen annak fényében, hogy a bizonyítékalapú testsúlycsökkentő kezelések a bariátriai megközelítés kivételével csak csekély és rövid távú eredményt hoznak [25]. A súlycsökkentő kezelések költséghatékonyságának optimalizálása és a fogyásra törekvők kudarcélményének minimalizálása érdekében kulcsfontosságú annak meghatározása, hogy mely kezeléstípus a leghatékonyabb az adott egyénnek. Ennek előfeltétele az elhízott populáció heterogén voltának (f)elismerése [40]. Számos páciens-kezelés illeszkedést elősegítő algoritmust dolgoztak ki. Ezek elsősorban biológiai vagy morfológiai változókon alapulnak, de tekintetbe vesznek egyéb tényezőket is [41]. A pszichológiai tényezőkre példa a distressz érzése, ami azért különösen fontos, mert a stressz és az általa keltett negatív érzések kritikusak az emocionális evés indukálásában [32]. Az érzelmi evés a negatív hangulati állapottal való emóciófókuszú, maladaptív copingstratégia [16], amely hosszú távon súlygyarapodással jár [21, 22], mert fokozott nassoláshoz, illetve túlevéshez vezet $[23,32]$. Érdemes hangsúlyozni, hogy a nyugati társadalomra jellemző, elhízással és elhízottakkal kapcsolatos negatív elöítélet és diszkrimináció $[6,8]$ krónikus stresszorként konceptualizálható, amely káros hatást gyakorolhat az emocionális jóllétre, és ahhoz vezethet, hogy az elhízott emberek az átlagos súlyúaknál több distresszt élnek át [12]. 
A kezelésválasztás során a stressz és a distressz érzésének felmérését szükséges lenne kiegészíteni az érzelmi evésre való hajlam felmérésével. Erre szolgál a Függelékben közölt Érzelmi evés skála [18, 19], amelynek segítségével a szakember percek alatt képet nyerhet arról, hogy szükséges-e foglalkoznia ezzel az obesogen evési magatartással vagy sem. Az érzelemszabályozási célból történő evés még akkor is gátolja a súlycsökkentő kezelés sikerességét, ha a páciens motivált és betartani törekszik az étrendre és a fizikai aktivitásra vonatkozó előírásokat. A páciensek sokszor szégyellik az érzelmi evésüket, mert az emocionálisan triggerelt evésrohamok során kontrollvesztést élhetnek át, és titokban akár a gyermekeik csokoládéját is befalhatják. Amennyiben a páciens hajlamos arra, hogy érzelemszabályozás céljából egyen, javasolt ezt normalizálni a szégyenérzet elkerülése érdekében. Érdemes rámutatni, hogy ez igen gyakori magatartás, sokan hajlamosak arra, hogy például a rosszkedvüket, szorongásukat, unalmukat evéssel csillapítsák vagy űzzék el. Egy, az Egyesült Államokban végzett reprezentatív kutatás eredményei szerint a résztvevők 43\%-a számolt be arról, hogy evéssel küzd meg a stresszel [42]. A súlyfelesleggel bírók számára igen hasznos, ha megismerik és megértik a stressz szerepét az evési magatartásuk alakulásában [15], illetve a fizikai éhség és az érzelmi éhség alapvető különbségeit [17]. Az edukáció során hangsúlyozandó, hogy a páciensnek érdemes tudatosítania, hogy mikor áll distresszérzés az éhsége hátterében; azonosítania az érzelmi evést kiváltó feszültség forrását; illetve lépéseket tennie a feszültség csökkentésének evésen túlmutató formái felé. A jelen tanulmányban közölt technikák mindegyike segíthet ez utóbbi cél elérésében.

A stresszkezelő készségek integrálása a hagyományos testsúlycsökkentő kezelésekbe azért különösen előnyös, mert növelheti a páciensek kezelési együttmúködését [32]. Az Európában lefolytatott randomizált, kontrollcsoportos klinikai vizsgálatok eredményei arra utalnak, hogy a standard kórházi súlycsökkentő kezelések kiegészítése relaxációs módszerekkel (például progresszív izomrelaxáció, alkalmazott relaxáció, diafragmatikus légzés) elősegíti az érzelmi evésre való hajlam csökkenését, az evés tudatos korlátozásának növekedését és (ezáltal) a fogyást [30-32]. A hatékony stresszkezelés azonban túlmutat a relaxáción, más készségeket is felölel, amelyek egy része az elhízás bizonyítékalapú kognitív viselkedésterápiás kezelésében már benne foglaltatik (például problémamegoldás, viselkedéses helyettesítés, nemet mondás) $[25,33]$. Ezek a technikák a családorvosi vagy bármely szakorvosi praxisban könnyen megvalósíthatók, akár pszichoterápiás kezelés nélkül, izoláltan is.

Létezik egy komplex program is, amely további elemekkel gazdagíthatja az elhízottak kezelését a stresszkezelő készségek tekintetében. A bizonyítottan hatékony Williams Életkészségek ${ }^{\circledR}$ Stresszkezelő és Kommunikációs Készségfejlesztő Program a fent említettek mellett további adaptív emóciófókuszú és problémafókuszú megküzdési stratégiákat, valamint kapcsolatépítő készsé- geket (empátia, hatékony beszéd, figyelmes hallgatás, pozitív megnyilvánulások) is tartalmaz $[43,44]$. Az életkészségek elsajátítása és mindennapos alkalmazása hozzájárulhat azon konfliktusok hatékony kezeléséhez, illetve megelőzéséhez, amelyekből az evésrohamok révén levezetést nyerő feszültségek származnak. A Semmelweis Egyetem Magatartástudományi Intézetében megtörtént a Williams Életkészségek ${ }^{\circledR}$ Stresszkezelő és Kommunikációs Készségfejlesztő Program adaptációja az elhízás problémakörére. Az első tíz csoporttal szerzett tapasztalatok fényében elmondható, hogy a program jól értelmezhetô és alkalmazható az elhízás és a testsúlykontroll kontextusában is [45]. Hasznos lenne e program integrálása egy orvosi team által vezetett testsúlycsökkentő kezelésbe, és a hatékonyságának tesztelése randomizált, kontrollcsoportos kutatási elrendezésben.

Anyagi támogatás: A szerző a Williams Életkészségek ${ }^{\circledR}$ Stresszkezelő és Kommunikációs Készségfejlesztő Program elhízás problémakörére való adaptálásához a Selye János Magyar Magatartástudományi és Magatartásorvoslási Társaság anyagi támogatásában részesült.

A szerző a közlemény végleges változatát elolvasta és jóváhagyta.

Érdekeltségek: A szakemberek továbbképzését szolgáló Williams Életkészségek ${ }^{\circledR}$ Stresszkezelő és Kommunikációs Készségfejlesztő Programokban való részvétel tanfolyam formájában, a résztvevők anyagi finanszírozásával történt.

\section{Irodalom}

[1] Hu, F. B.: Obesity epidemiology. Oxford University Press, New York, 2008.

[2] Central Statistical Office: European population health survey 2014. [Központi Statisztikai Hivatal: Európai lakossági egészségfelmérés, 2014. Statisztikai Tükör, 2015, (29), 1-9. [Hungarian]

[3] Németh, Á.: Body image, nutritional status, body weight control. In: Németh, Á., Költő, A. (eds.): Health Behaviour in Schoolaged Children (HBSC): A WHO-collaborative Cross-National Study National Report 2010. [Testkép, tápláltsági állapot, testtömegkontroll. In: Németh, Á., Költő, A. (szerk.): Serdülőkorú fiatalok egészsége és életmódja 2010. Az Iskoláskorú gyermekek egészségmagatartása címú, az Egészségügyi Világszervezettel együttmúködésben zajló nemzetközi kutatás 2010. évi felmérésérôl készült nemzeti jelentés.] Országos Gyermekegészségügyi Intézet, Budapest, 2011. [Hungarian]

[4] Luppino, F. S., de Wit, L. M., Bouvy, P. F., et al.: Overweight, obesity, and depression. A systematic review and meta-analysis of longitudinal studies. Arch. Gen. Psychiatry, 2010, 67(3), 220229.

[5] Selye, J.: Stress without distress. [Stressz distressz nélkül.] Akadémiai Kiadó, Budapest, 1976. [Hungarian]

[6] Publ, R., Brownell, K. D.: Bias, discrimination, and obesity. Obes. Res., 2001, $9(12), 788-805$.

[7] Publ, R. M., Latner, J. D.: Stigma, obesity, and the health of the nation's children. Psychol. Bull., 2007, 133(4), 557-580. 


\section{Háromfaktoros Evési Kérdőív - Érzelmi evés skála ${ }^{1}$}

A következő kérdőív az étkezési szokásaival és az éhségérzettel kapcsolatban tartalmaz állításokat és kérdéseket. Kérjük, olvassa el figyelmesen az állításokat, és karikázza be azt a választ, amely a leginkább érvényes Önre!

\section{Amikor szorongok, enni kezdek.}

1. Teljes mértékben igaz.

2. Többnyire igaz.

3. Többnyire nem igaz.

4. Egyáltalán nem igaz.

2. Amikor szomorú vagyok, gyakran túl sokat eszem.

1. Teljes mértékben igaz.

2. Többnyire igaz.

3. Többnyire nem igaz.

4. Egyáltalán nem igaz.

3. Amikor feszült vagyok vagy fel vagyok húzva, gyakran úgy érzem, hogy ennem kell.

1. Teljes mértékben igaz.

2. Többnyire igaz.

3. Többnyire nem igaz.

4. Egyáltalán nem igaz.

4. Amikor magányos vagyok, evéssel vigasztalódom.

1. Teljes mértékben igaz.

2. Többnyire igaz.

3. Többnyire nem igaz.

4. Egyáltalán nem igaz.

1 TFEQ-R2 1 v 1.2, UK ${ }^{\odot} 2000$. HRQL group - Göteborg University on Campus Company, Göteborg, Sweden. All Rights Reserved.
5. Amikor ideges vagyok, evéssel próbálom megnyugtatni magam.

1. Teljes mértékben igaz.

2. Többnyire igaz.

3. Többnyire nem igaz.

4. Egyáltalán nem igaz.

6. Amikor levert vagyok, enni akarok.

1. Teljes mértékben igaz.

2. Többnyire igaz.

3. Többnyire nem igaz.

4. Egyáltalán nem igaz.

Leírás:

A 21 tételes Háromfaktoros Evési Kérdőív [18-19] Érzelmi evés skálája az arra való hajlamot méri fel, hogy a személy túleszik-e negatív kedélyállapot esetében, például amikor magányosnak, kedvetlennek érzi magát vagy szorong.

\section{Skálaképzés:}

Pontozás: Valamennyi tétel fordított ( $1=4$ pont; $2=$ 3 pont, $3=2$ pont; $4=1$ pont).

Számítása: A tételek megfordítása után összeadni és átlagolni a tételeket.

Referenciaadatok hazai mintákon:

Egyetemi hallgatónők [19]: átlag 1,9 pont $(\mathrm{SD}=$ $0,74)$.

Életmódváltó program résztvevői [46]:

- normális súlyúak (BMI: 18,5-24,9): átlag 1,5 pont $(\mathrm{SD}=0,62)$;

- súlyfelesleggel élők $(\mathrm{BMI} \geq 25,0)$ : átlag 1,8 pont $(\mathrm{SD}=0,77)$.

Intézeti súlycsökkentő program résztvevői (BMI $\geq 25,0[46]$ ):

- férfiak: átlag 2,0 pont $(S D=0,78)$;

- nők: átlag 2,5 pont $(S D=0,89)$.
[8] Publ, R. M., Heuer, C. A.: The stigma of obesity: A review and update. Obesity, 2009, 17(5), 941-964.

[9] Kende, A., Bernáth, D.: Children's implicit rejection of overweight people. [A túlsúlyos emberek implicit elutasítása gyerekkorban.] Mentálhigiéné és Pszichoszomatika, 2012, 13(4), 339373. [Hungarian]

[10] Papp, I., Túry, F.: The stigmatization of obesity among Gypsy and Hungarian children. Eat. Weight Disord., 2013, 18(2), 193-198

[11] Papp, I., Czeglédi, E., Túry, F.: The association between sociocultural effects and bias against obese people at preadolescence ages. [A szociokulturális hatások kapcsolata az elhízottakkal szembeni előítéletekkel kora serdülőkorban.] Mentálhigiéné és Pszichoszomatika, 2011, 12(2), 149-171. [Hungarian]

[12] Fabricatore, A. N., Wadden, T. A.: Psychological functioning of obese individuals. Diabetes Spectr., 2003, 16(4), 245-252.

[13] De Vriendt, T., Moreno, L. A., De Henaww, S.: Chronic stress and obesity in adolescents: Scientific evidence and methodological issues for epidemiological research. Nutr. Metab. Cardiovasc. Dis., 2009, 19(7), 511-519.

[14] Stults-Kolehmainen, M. A., Sinha, R.: The effects of stress on physical activity and exercise. Sports Med., 2014, 44(1), 81-121.

[15] Torres, S. J., Nowson, C. A.: Relationship between stress, eating behavior, and obesity. Nutrition, 2007, 23(11-12), 887-894. 
[16] Faith, M. S., Allison, D. B., Geliebter, A.: Emotional eating and obesity: Theoretical considerations and practical recommendations. In: Dalton, S. (ed.): Overweight and weight management: the health professional's guide to understanding and practice. Aspen Publishers, Gaithersburg, 1997, 439-465.

[17] Doğan, T., Göçet Tekin, E., Katrancroğlu, A.: Feeding your feelings: A self-report measure of emotional eating. Procedia Soc. Behav. Sci., 2011, 15, 2074-2077.

[18] Tholin, S., Rasmussen, F., Tynelius, P., et al.: Genetic and environmental influences on eating behavior: the Swedish Young Male Twins Study. Am. J. Clin. Nutr., 2005, 81(3), 564-569.

[19] Czeglédi, E., Urbán, R.: Hungarian adaptation of Three-Factor Eating Questionnaire Revised 21-Item. [A Háromfaktoros Evési Kérdőív (Three-Factor Eating Questionnaire Revised 21-Item) hazai adaptációja.] Magy. Psychol. Szle, 2010, 65(3), 463-494. [Hungarian]

[20] Péneau, S., Ménard, E., Méjean, C., et al.: Sex and dieting modify the association between emotional eating and weight status. Am J. Clin. Nutr., 2013, 97(6), 1307-1313.

[21] Koenders, P. G., van Strien, T.: Emotional eating, rather than lifestyle behavior, drives weight gain in a prospective study in 1562 employees. J. Occup. Environ. Med., 2011, 53(11), 1287-1293.

[22] Sung, J., Lee, K., Song, Y. M.: Relationship of eating behavior to long-term weight change and body mass index: the Healthy Twin study. Eat. Weight Disord., 2009, 14(2-3), e98-el05.

[23] Konttinen, H., Männistö, S., Sarlio-Lähteenkorva, S., et al.: Emotional eating, depressive symptoms and self-reported food consumption. A population-based study. Appetite, 2010, 54(3), 473-479.

[24] Wurtman, R. J., Wurtman, J. J.: Brain serotonin carbohydratecraving, obesity and depression. Obes. Res., 1995, 3(Suppl. 4), 477S-480S

[25] Wadden, T. A., Stunkard. A. J. (eds.): Handbook of obesity treatment. Guilford Press, New York, 2004.

[26] Czeglédi, E.: The application of the transtheoretical model of behavior change for the treatment of obesity. [A viselkedésváltozás transzteoretikus modelljének alkalmazási lehetőségei az elhízás kezelésében.] Mentálhigiéné és Pszichoszomatika, 2012, 13(4), 411-434. [Hungarian]

[27] Cooper, Z., Fairburn, C. G., Hawker, D. M.: Cognitive-behavioral treatment of obesity. A clinician's guide. Guilford Press, New York, London, 2003.

[28] Cooper, Z., Fairburn, C. G.: A new cognitive behavioural approach to the treatment of obesity. Behav. Res. Ther., 2001, $39(5), 499-511$.

[29] Buckroyd, J., Rother, S.: Therapeutic groups for obese women. A Group Leader's Handbook. John Wiley \& Sons Ltd., Chichester, 2007.

[30] Manzoni, G. M., Gorini, A., Preziosa, A., et al.: New technologies and relaxation: an explorative study on obese patients with emotional eating. J. Cyber Ther. Rehabil., 2008, 1(2), 182-192.

[31] Manzoni, G. M., Pagnini, F., Gorini, A., et al.: Can relaxation training reduce emotional eating in women with obesity? An exploratory study with 3 months follow-up. J. Am. Diet. Assoc., 2009, 109(8), 1427-1432.
[32] Christaki, E., Kokkinos, A., Costarelli, V., et al.: Stress management can facilitate weight loss in Greek overweight and obese women: a pilot study. J. Hum. Nutr. Diet., 2013, 26(Suppl. 1), 132-139.

[33] Jones, L. R., Wadden, T. A.: State of science: Behavioural treatment of obesity. Asia Pac. J. Clin. Nutr., 2006, 15(Suppl.), 3039.

[34] Mórotz, K., Perczel Forintos, D.: Cognitive behavioral therapy. [Kognitív viselkedésterápia.] Medicina Könyvkiadó, Budapest, 2006. [Hungarian]

[35] McInnis, K. J., Franklin, B. A., Rippe, J. M.: Counseling for physical activity in overweight and obese patients. Am. Fam. Physician, 2003, 67(6), 1249-1256.

[36] Clow, A., Edmunds, S. (eds.): Physical activity and mental health. Human Kinetics, Leeds, 2014.

[37] Byrne, S. M., Cooper, Z., Fairburn, C. G.: Psychological predictors of weight regain in obesity. Behav. Res. Ther., 2004, 42(11), 1341-1356.

[38] Herman, C. P., Polivy, J.: The self-regulation of eating: theoretical and practical problems. In: Baumeister, R. F., Vohs, K. D. (eds.): Handbook of self-regulation: research, theory, and applications. Guilford Press, New York, 2004.

[39] Grilo, C. M.: Treatment of obesity: An integrative model. In: Thompson, J. K. (ed.): Body image, eating disorders, and obesity. American Psychological Association, Washington, 2000.

[40] Teixeira, P. J., Going, S. B., Sardinha, L. B., et al.: A review of psychosocial pre-treatment predictors of weight control. Obes. Rev., 2005, 6(1), 43-65.

[41] Wadden, T. A., Brownell, K. D., Foster, G. D.: Obesity: Responding to the global epidemic. J. Consult. Clin. Psychol., 2002, $70(3), 510-525$.

[42] Groesz, L. M., McCoy, S., Carl, J., et al.: What is eating you? Stress and the drive to eat. Appetite, 2012, 58(2), 717-721.

[43] Williams, V. P., Brenner, S. L., Helms, M. J., et al.: Coping skills training to reduce psychosocial risk factors for medical disorders: a field trial evaluating effectiveness in multiple worksites. J. Occup. Health, 2009, 51(5), 437-442.

[44] Stauder, A., Konkoly Thege, B., Kovács, M. E., et al.: Worldwide stress: Different problems, similar solutions? Cultural adaptation and evaluation of a standardized stress management program in Hungary. Int. J. Behav. Med., 2010, 17(1), 25-32.

[45] Czeglédi, E.: The role of stress management in weight control. Obesitol. Hung., 2015, 14(S2), 18

[46] Czeglédi, E.: Psychological correlates and interventional possibilities of obesity in adulthood. Doctoral thesis. [A felnőttkori elhízás pszichológiai korrelátumai és intervenciós lehetőségei. Doktori értekezés.] ELTE PPK, Budapest, 2012. [Hungarian]

(Czeglédi Edit dr., Budapest, Nagyvárad tér 4., 1089 e-mail: czedit@gmail.com) 